\title{
Sciendo
}

10.2478/topling-2020-0009

\section{On body-part nouns and the expression of spatial and locative reference in Dagbani}

\author{
Samuel Alhassan Issah* \\ University of Education, Ghana
}

\begin{abstract}
This paper examines the linguistic means by which spatial relations are expressed in Dagbani, a Mabia (Gur) language spoken in the northern region of Ghana (West Africa). I pay particular attention to the grammar of Dagbani "postpositions" demonstrating that the system of locative expressions comprises words that share heterosemic relations with some body parts and landmark terms. I show that although these locative expressions are related both segmentally and suprasegmentally to the nominal items they might have developed from, they are distinct in terms of their semantic, syntactic and morphological properties. Consequently, I conclude that the body-part nouns in locative constructions are distinct syntactic categories due to the morphosyntactic and semantic differences they exhibit. These body-part nouns are thus analysed as grammaticalized items, which function as postpositions and instantiate a postpositional phrase (PostP) category. Finally, I propose possible series of semantic changes that could account for the development of the body-part terms as postpositions.
\end{abstract}

\section{Key words}

Dagbani, lexical category, grammaticalization, postpositions, Mabia, spatial reference, location

\section{Introduction}

Dagbani, a major language of Northern Ghana belongs to the South-Western Oti-Volta subgroup of the Mabia (Gur) group of languages (Bendor-Samuel, 1971; Naden, 1988; 1989). It is a member of the Southeastern subgroup of Western Oti-Volta languages, in the group now called Mabia. Dagbani is spoken mainly by the Dagbamba who are found mostly in the Northern Region of Ghana. Bodomo (1994 et seq) suggests the indigenous term Mabia as a classificatory term for this group of languages which were hitherto called the Gur languages. The cultural affinities that exist among these languages motivate the suggestion of this indigenous terminology. Some other Mabia (Gur) languages, which are somewhat close to Dagbani in terms of linguistic features, are Dagaare, Mampruli, Safaleba, Kusaal and Gurune.

The main focus of this paper is to show that noun forms used in expressing spatial grammar are better treated as postpositions rather than as nouns or "relator nouns", as some scholars have referred to them. This conclusion is because although they originate from nouns via a grammaticalization process, they exhibit morpho-syntactic and semantic characteristics distinct from nouns. The paper sets out to address the following questions: (i) How is spatial grammar expressed in Dagbani? (ii) Should body-part nouns used in spatial constructions be analysed as a syntactic category distinct from nouns? (iii) How do we account for the derivation of ní-constructions in Dagbani spatial grammar and finally (iv) How can we account for the development of body-part nouns into grammaticalized items of postpositions in Dagbani?

\footnotetext{
* Address for correspondence: Samuel Alhassan Issah, Department of Gur-Gonja Education, Faculty of Ghanaian Languages Education, University of Education, Winneba, Post Office Box 72, Ajumako, Ghana. Email: samuel_issah@yahoo.com
} 
The data used in this paper is an outcome of my interactions with students, especially level 200 students of the Dagbani Unit of the Department of Gur-Gonja Education of the University of Education, Winneba. While discussing postpositions with them, I set up various locative relationships and asked them to describe them for me. The method resulted in a very interactive class and gave us an opportunity to describe diversified locative relations in the language. Consequently, it also afforded us the opportunity to describe more sophisticated locative relationships than I could imagine, and so the method was found very useful. This methodology also dramatically challenged the students to produce very interesting data expressing different spatial relations I would not have arrived at if I had to construct the data using my native intuitions.

There is no literature that describes the spatial constructions of Dagbani. The data presented in this paper was hitherto unknown and is therefore an original contribution to the description of an aspect of the grammar of the Dagbani language that has not, until now, received attention from scholars. The choice of this topic is because studies in spatial reference and locative constructions have long been a popular topic in linguistic research. Researchers have published several pieces of linguistic research on the subject over the years. However, none of this research is on linguistic data from Dagbani. The data from Dagbani will therefore be essential in contributing to knowledge in this area of language study. This paper does not claim to challenge theoretical proposals within which spatial constructions are studied. However, although mainly empirically driven, some parts of the paper invoke theoretical assumptions that help to throw more light on the empirical material. Although Dagbani does not mark tone in the current orthography, I have marked tone on the data used in this paper. This is useful because it helps to show that these grammaticalized postpositions do not only have same morphological forms as their nominal counterparts but also bear the identical suprasegmental feature of tone.

Beyond this section, the paper proceeds as follows: Section 2 outlines the coding of spatial and locative reference in languages where I briefly discuss the various strategies that are employed for the marking of spatial grammar in languages. In Section 3, I present details on the basic locative structure in Dagbani and some other areal languages. The aim is to show that the use of nouns to code locative reference is not a phenomenon peculiar to Dagbani but characteristic of areal languages, whereas Section 4 discusses the coding of spatial grammar in Dagbani focusing on the locative marker $n i$ and the use of body-part nouns. The section employs syntactic, semantic and morphological criteria, which serve as evidence for my proposal that these body-part nouns used as spatial markers are a distinct class of syntactic category labelled as postpositions. In Section 5, I focus on the development of bodypart postpositions. Here, I propose that the use of these nominal items as postpositions stems from the framework of grammaticalization where these nominal words grammaticalize into functional morphemes via metonymic and metaphorical extensions as a possible course of development. Section 6 concludes the paper.

\section{The coding of spatial and locative reference in languages}

Heine et al. (1991) note that different languages have different ways of expressing location. For instance, European languages such as English do it with the use of a "closed" group of grammatical words called prepositions. The class of prepositions are a part of speech/category with the following properties; they generally do not take any inflectional affixes; cross-linguistically, they are a closed class of words as other grammatical categories such as auxiliaries, conjunctions, determiners and pronominals. Thus, prepositions are a finite set of words in languages. Although it seems quite challenging to identify prepositions by any formal features, one syntactic feature that seems prominent with all prepositions in languages is that they generally precede a nominal phrase (NP) complement. Whether a language is said to have postpositions or prepositions is a matter of the syntactic positions that its locative expressions take in relation to the complement; that is, whether it precedes or follows the complement. Adposition is the generic term for prepositions and postpositions. They generally have locative functions in languages and locate an object, often called a figure, in a relation to one or several objects. A widely held view in the study of spatial grammar is that the natural meaning of a locative is a relation in space. As previously pointed out, in some languages they are a closed class of lexical items, derived diachronically from nouns and verbs (Payne, 1997; Ameka and Essegbey, 2006). It is possible for some languages to have both prepositions and postpositions, as reported in (Ameka, 2003). 
According to Heine et al. (1991), adpositions are a class of words that are employed to express spatial or temporal relation. They further contend that these words are derived from concrete nouns such as body parts or environmental landmarks and that the locative notions which are totally abstract are expressed in terms of visible, tangible objects, indicating a derivation of spatial concepts from concrete nouns. They argue that adposition elements such as on, under, in, front and back etymologically belong to the class of nouns and adverbials but have drifted away from their respective lexical source. Thus, they have lost their nominal or adverbial properties due to their generalized used in denoting an "adpositional concepts". Heine et al. (1991) exemplify these using examples from Hausa as in, cikin 'in, inside', cikii 'stomach', gaban 'in front of, before' gabaa 'front part of body' and baayan 'behind, after' baayaa 'the back'. In their work, they identify two types of adpositions: $\mathrm{N}$-adposition (noun-based adposition) and $\mathrm{V}$-adposition (verb-based adposition). These two have contrasting syntactic functions and differ in their grammaticalization behaviour. In addition to that, whilst its relation to the noun phrase syntactically determines the $\mathrm{N}$-adposition it governs, $\mathrm{V}$-adposition is defined with reference to the valency of the main verb. Their semantic properties overlap to the extent that some languages do not distinguish between the two. Nevertheless, they explain that $\mathrm{N}$-adpositions typically describe a spatial relation, whereas $\mathrm{V}$-adpositions may define either a direction or a point.

Following the categorization of adpositions proposed by Heine et al. (1991), I suggest that Dagbani has $\mathrm{N}$-adpositions, which typically reflect the fact that the adpositions of the language emerge from nominal sources. Heine et al. (1991) further claim that "viewed from the perspective of Ewe, Hausa or Maa, prepositions in European languages may be called portmanteau markers, since they combine the function of both V-and N-adpositions". Heine et al. (1991) further classify spatial adpositions into two main classes, namely directional and static ones. A directional adposition usually involves motion along a path over time, but can also denote a non-temporal path. Examples of directional adpositions include to, from, towards, into, along and through. A static adposition, on the other hand, does not involve movement. Examples of these in English include at, in, on, beside, behind, under and above. ${ }^{1}$ The static type of adpositions in Dagbani is the topic of discussion in this paper.

The study of spatial grammar in Ghanaian languages has been a rather exciting topic. The main controversy is whether there are postpositions/prepositions in these languages, and if there are, how they are distinct from other grammatical categories in these languages. One notable generalization for most Ghanaian languages in the study of syntactic categories is the view that these languages have postpositions rather than prepositions. Research has shown that in languages such as Ewe (Duthie, 1988), Dagaare (Saanchi, 2005; 2014), Ga (Dakubu, 1988), Awutu (Frajzyngier, 1974), Akan (Christaller, 1875) and Gurunc (Atintono, 2012a; 2012b; 2013), the class of closed words that code spatial relations are postpositions derived from nouns. This has consequently led to the establishment of a syntactic category labelled as postpositions. According to Christaller (1875:76ff), Boadi (2010) and Osam et al. (2011), some languages have postpositions which are nouns and code relational semantics just like English prepositions do. It should be noted that Osam et al. (2011), however, propose that some morphemes Akan uses to code spatial grammar are relator nouns rather than postpositions. The authors support this argument with the claim that the two have the same morphosyntactic characteristics in Akan.

The study of how languages express space and spatial relations is a fascinating topic in Ghanaian (Mabia) linguistics. This stems from the fact that the words which are used to code the grammar of space and the landmark of an entity in relation to another are derived from nominal sources consisting of bodyparts, lands and parts of some objects and sometimes also as verbs (Heine et al. 1991; Payne, 1997; Ameka, 2003; Ameka and Levinson, 2007). Consequently, there has been a lot of debate as to whether these words should be analysed as comprising a syntactic category different from nouns/verbs, or just as nouns, and if either, what the empirical pieces of evidences to motivate either account would be. Dagbani expresses spatial location via the use of postpositions, which are derived from nouns as found in languages such as Japanese, Turkish and Hindi (Lyons, 1968; Kuno, 1973). As has been briefly pointed out, in Dagbani, postpositions are words identical in form to nominal words, which in most cases refer to some body-parts and in some cases landmark terms.

The use of body-part terms in locative expressions is a common feature of most languages: Dagaare (Saanchi, 2005), Zapotec (MacLaury, 1989; Lillehaugen, 2003), Kî̂tharaka (Muriungi, 2006) Ewe

\footnotetext{
${ }^{1}$ For now, I ignore the fact that these static adpositions are also used directionally.
} 
(Duthie, 1996; Ameka, 2003; Ameka and Essegbey, 2006), Akan (Boadi, 1992; 2010; Osam et al., 2013) to mention just a few.

MacLaury (1989, p. 120), arguing about a non-Valley Zapotec language, Ayoquesco Zapotec, postulates that:

[the] body-part locatives are not prepositions because there is no justification for setting them apart from their primary classification as nouns. Unlike English prepositions, they are identical in form to the nouns applied to body organs, their use in syntax is optional, they only add specificity to other locative expressions, they do not complicate syntax, they do not denote direction, and they do not mark grammatical relations as do case markers.

Boadi (2010, pp. 227-228) also asserts that though the postpositional system of Akan is made up of nouns, these nouns follow their complements as nominals of languages that have postpositions and function as heads of postpositional phrases. He further suggests that semantically, these nominal words in locative constructions express spatial and locative functions.

Having outlined the fact that varied categories code spatial grammar in languages of the world, in the next section, I provide an overview of the basic locative structure in Dagbani and other areal languages.

\section{Basic locative structure in Dagbani and some other areal languages}

This section aims to characterize and explain the basic locative structure in Dagbani. It further focuses on the relationship with English, the metalanguage, one Kwa language and one Mabia (Gur) language. The discussion further aims to elucidate the idea of preposition noun, and postposition in Dagbani. The discussion draws data from Kusaal based on Musah (2018), and Akan (Osam et al., 2011). In his discussion on the grammar of locative expressions in Kusaal, Musah (2018) contends that the items that are used to code spatial and/or temporal relation are achieved via the use of lexical items that are derived from nominal sources. He identifies some of these as zug 'head', gbin 'buttock', nəor 'mouth', pvorg

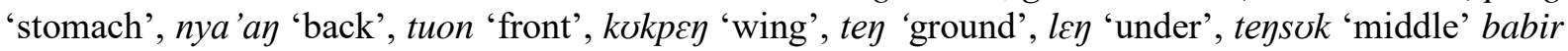
'area', all of which consist of landmarks and body-parts. The sentences in (1) taken from Musah (2018) exemplify the use of these nominal items in expressing spatial grammar.

(1) a.

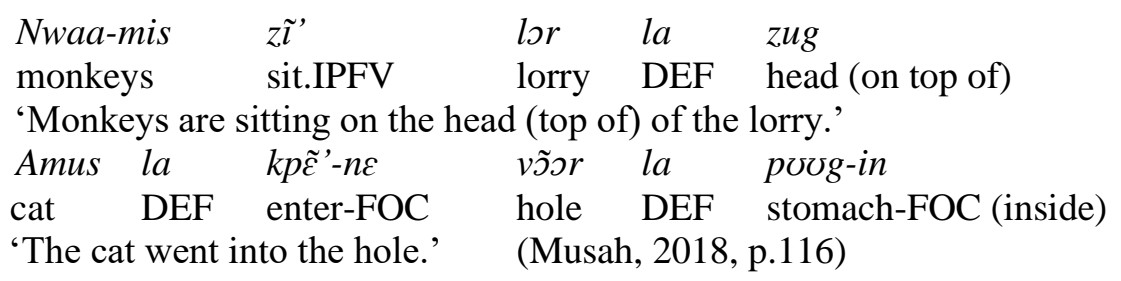

He refers to this class of nouns as relator nouns. In (1a) for instance, zug expresses spatial or spatial relation between the monkeys and lorry. Similar facts hold for povg in (1b) which is also used to express spatial grammar. Regarding the derivation of the positional reading of povg, it is worthy of mention as we will soon observe for Dagbani that the morpheme -in has similar distributional features to ní of Dagbani, which I analyse as a general locative marker that augments some of the body-part nouns in the derivation of the spatial interpretation in section 4.1. Abubakari (2018) also discusses spatial references in Kusaal and shows that some expressions that occur in spatial constructions originate from nouns.

The fact that languages derive locative expressions from nouns is not a peculiar linguistic characteristic of languages within the Mabia (Gur) family, but also within the Kwa languages. For instance, Osam et al. (2011) show that one established claim in the study of syntactic categories in Akan is the fact that the language has postpositions rather than prepositions. Although they admit that the distribution of these items in constructions might be the defining factor in labelling them as postpositions, it is better to refer to them as relator nouns. According to Post (2007, p. 374), a relator noun is "a functional subclass of noun (or a class of function words which are historically derived from nouns, and which continue to resemble nouns in significant respects) which stand in a modifying syntactic relation to a distinct, lexical head noun. Most often, relator nouns encode spatial or locational 
concepts, but they may also denote types of temporal or conceptual relations (which may or may not be relatable to spatial concepts)." As Osam et al. outline, Christaller (1875, p.74) contends that in Akan, "the prepositions of European and other languages are expressed in Tshi [Twi] by a class of auxiliary verbs, which we may call prepositional verbs ... by postpositions, which are in fact nouns (of place and relation)." (Christaller, 1875, pp. 74-75) further notes that the prepositional verbs are used to code "relations of place", "relations of time", "relations of manner, degree, instrumentality, accompaniment and exclusion" and "relations of cause, concern, aim, intention and purpose". Following earlier writers in Akan such as Christaller (1875), Balmer and Grant (1929) among others, Osam et al. admit that the language makes use of both "prepositions" and "postpositions" albeit they contend that the latter should be called relator nouns. Secondly, the authors are of the view that these relator nuns (postpositions) are indeed nouns, suggesting that Akan lacks prepositions, which exactly correspond to those of a language such as English. Christaller (1875, p. 77) identifies eight words in Akan "chief nouns of place and relations" which are used like prepositions in English. They include àsé 'down, under', hó 'side,' mú 'inside,' àní 'eye,' ànó 'mouth', àním 'front', àkyí 'back', and só 'top'.

Notwithstanding the prevalence of the term "relator nouns" in describing the nominal items used in expressing location, Balmer and Grant (1929) prefer that they be called postpositions instead. They therefore assume that "In Fante, there are no prepositions exactly corresponding to those in English. The words used as equivalents of prepositions are either nouns or verbs [...] it may be said that prepositions are particles that have become worn down from larger words which were once fuller and more concrete in meaning, such as nouns are." (Balmer and Grant, 1929, p. 54). The data below, taken from Osam et al. (2011) illustrate the use of body-part nouns which are used to code the space, location or landmark of one entity in relation to another.

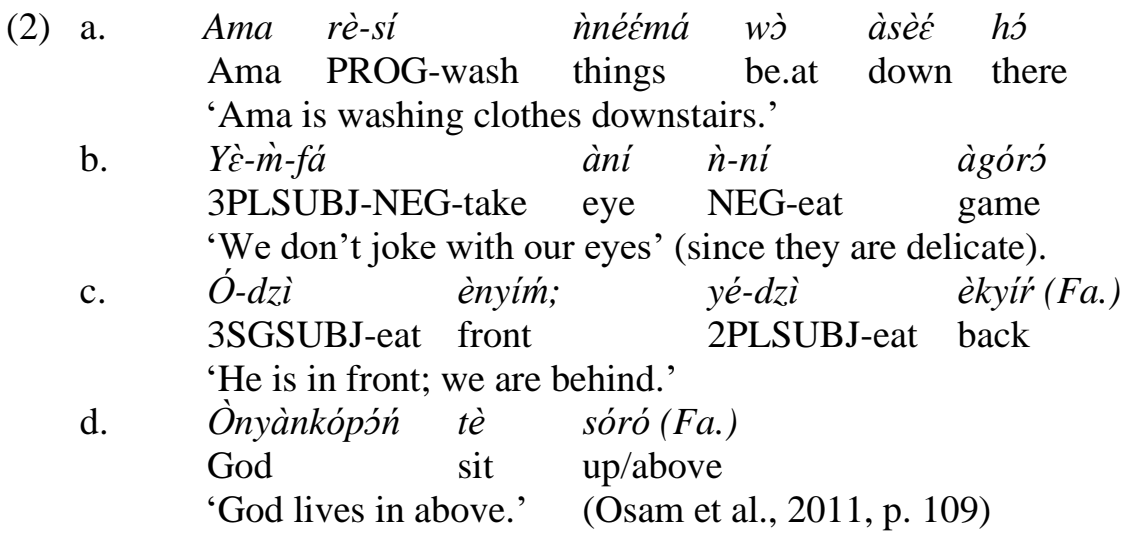

Osam et al. (2011, p. 109) admit that these postpositions originate from nouns although they are better accounted for within the framework of grammaticalization. They categorise these words as relator nouns rather than postpositions. They base their conclusions on the morphological, syntactic and semantic properties they exhibit, which seem to be typical of nouns. This is understandable considering the claim of Heine et al. (1991) that adpositions possess some degree of noun traits since they are originally nouns.

In his grammatical sketch of Dagbani, Olawsky (1999) admits that there is a syntactic category in Dagbani labelled as postpositions, although he further points out that "most postpositions are actually nouns" (Olawsky, 1999, p. 16). He however does not lose sight of the fact that the language also makes use of prepositions although postpositions constitute the majority of Dagbani adpositions. He uses the generic term adpositions to refer to prepositions and postpositions and contends that the latter distributionally, occur after nouns. Olawsky (1999, p. 25) identifies words such as nyaanga 'back', zuyu 'head', puuni 'stomach', gbinni 'bottom', polo 'place', sunsuuni 'middle', sani 'there-in', and logni 'throat-in'. Thus, Dagbani shares some parallelism with Akan and Kusaal where postpositions have been analysed as items that originate from nouns. I exemplify this in (3). ${ }^{2}$

\footnotetext{
${ }^{2}$ I have modified all examples taken from Olawsky (1999) via the addition of tones.
} 
(3) a. yilí máá nyááyà

house DEF behind

'behind the house'.

b. yílí máá zúyù

house DEF on top of

'on top of the house'.

c. yílí máá pùùní

house DEF inside

'inside the house'. (Olawsky, 1999, p. 24)

Now, we consider the data in (4) which show how these nominals are grammaticalized into postpositions in Dagbani.

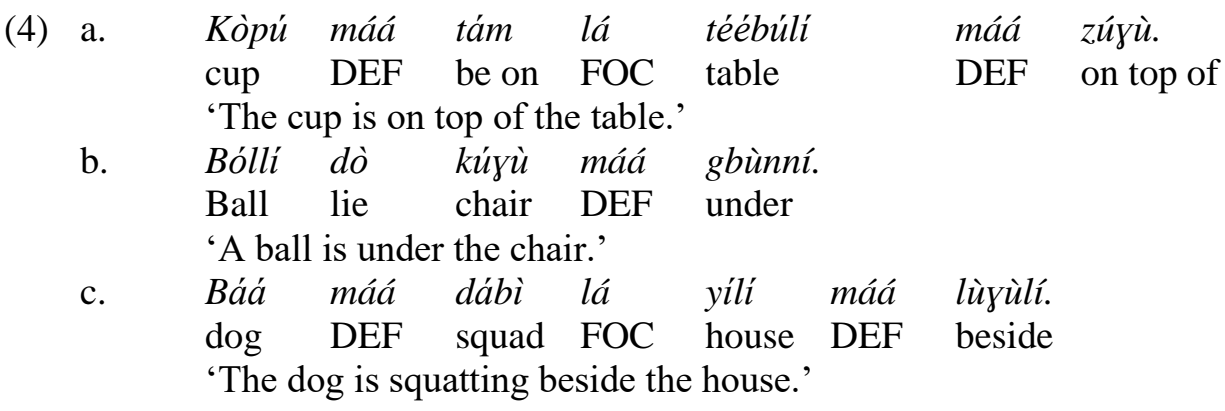

One fact that deserves mention is the fact that the semantics of the verbs also play a role in the expression of this notion of spatial grammar. For instance, in (4a) the verb do 'lie' is not allowed in that context and in the same manner tam 'be on' would not be appropriate in (4b). ${ }^{3}$ From the data presented in (4), it is evident that the claim in the literature that there are two basic notions in the linguistics of space is valid for Dagbani. These include figure and ground. Following Talmy (1983, p. 232) among others, I define "figure" "as the object that is considered as moving or located with respect to another object", whereas "ground" refers to "the object with respect to which a figure is considered as moving or located." Thus in (4a) for instance, while kòpú 'cup' is the figure, téébúli 'table' is the ground. Thus, figure and ground refer to the located and locating entity respectively.

Olawsky (1999, p. 25) further admits that with the exception of $n i$, which he calls a "real postposition", the majority of the Dagbani postpositions are nouns which are used "with adpositional function". This conclusion drawn of $n i$ is supported by the fact that "it does not have any meaning related to a noun" (Olawsky, 1999, p. 25).

Finally, as already pointed out, Olawsky (1999) notes that apart from the fact that Dagbani uses postpositions to code spatial relations, there are also a few words which can be described as prepositions. In fact, he notes that "there are the two prepositions ní and jéndì" (Olawsky, 1999, p. 25) as exemplified in (5).
(5) a
jéndì àdíní.
about religion
b. ní kpání.
with spear
'With a spear' (Olawsky, 1999, p. 25).

\footnotetext{
${ }^{3}$ I take cognizance of the fact that the use of the postpositional terms in Dagbani seems to employ some selective verbs in expressing the spatial relations between the Figure and the Ground. In the current paper however, I do not focus on the semantics of verbs in coding the location of objects in space and hope that this semantics domain could be an area of future research.
} 
With the account of the particle ní, which appears to be a marker for a general locative relation, as a preposition in Dagbani, I contend that $n i$ is not a postposition. Regarding the linguistic behaviour of ní compared to body-part terms when they express spatial relations, I contend that when used as a preposition ni precedes the NP and with it can express location, whereas it can also combine with body parts to express postpositions. There is however, no evidence to suggest that ní has a body-part heritage in Dagbani.

To sum up, the examples presented here have demonstrated that the grammaticalization of body-part nouns into postpositions is not a linguistic characteristic of only Dagbani and other Mabia (Gur) languages, but also pervasive in Kwa languages.

\section{The coding of spatial grammar in Dagbani}

The goal of this section is to offer an account of the coding of spatial grammar in Dagbani. The scope of the discussion focuses on the general locative marker ní, which occurs in locative constructions and the use of body-part nouns in expressing spatial grammar. I will start with the former.

\subsection{The particle ni and locative constructions}

This subsection discusses the distribution of ní in Dagbani locative constructions. This is important because a discussion on the particle $n i$ is helpful in understanding the body-part postpositions discussed in the paper. The morpheme ní generally expresses location in Dagbani (6). In such context, ní generally follows NPs and has the sense of 'in'. When NPs are absent, it results in the formation of ungrammatical sentences as in (6b, 6d and 6f). This $n i$, as the data below show, is potentially capable of co-occurring with other nouns. When this happens, it has the interpretation 'in'. When it, for instance, occurs with zúyù, 'head', it does not have the meaning of 'on top of', but rather carries the meaning of 'in' as observed in (6c).

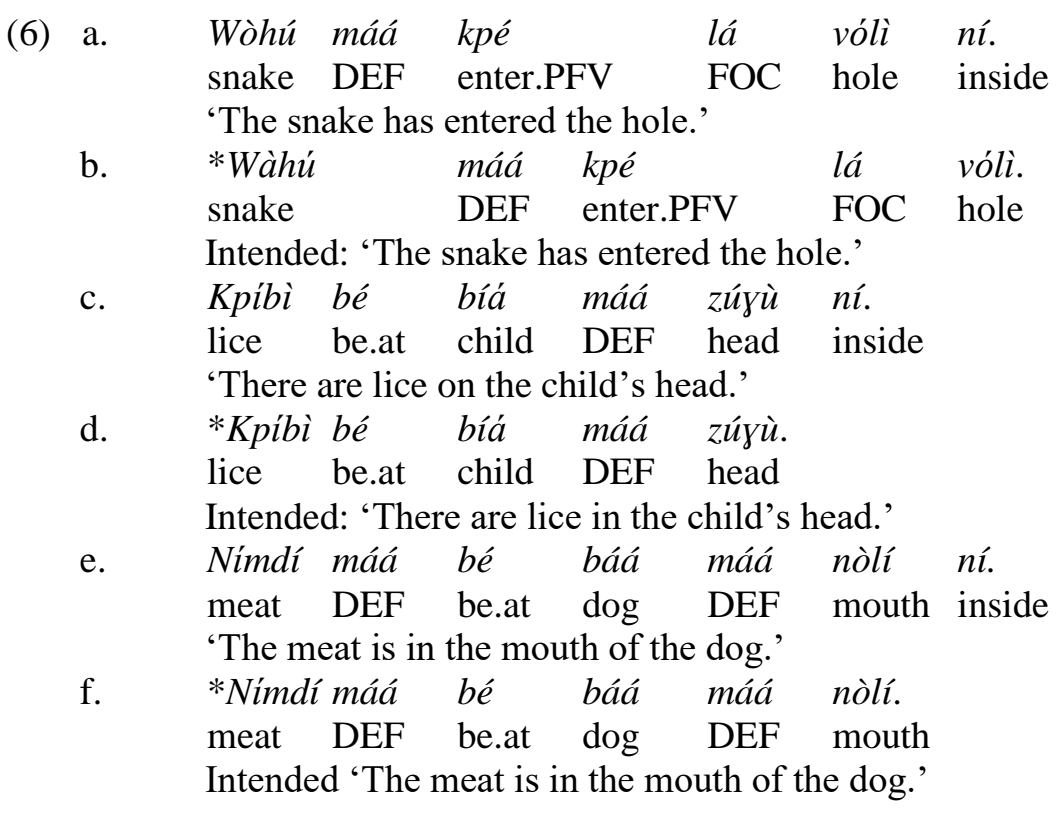

Although it has been pointed out that ní generally combines with nouns to express spatial notion, it should be mentioned that this particle is in complementary distribution with body parts that already contain the ní-segment as in pùùní 'inner layer of the stomach', gbùnní 'buttock', and tòòní 'front'. This means that the general locative $n i ́$ is already embedded in body-part nouns. This claim that body-part terms that contain $n i$ do not require the presence of the locative morpheme ní within the same syntactic domain is illustrated by the grammatical sentences $(7 \mathrm{a}, 7 \mathrm{c}, 7 \mathrm{e})$ and illicitness of $(7 \mathrm{~b}, 7 \mathrm{~d})$. 


\begin{tabular}{|c|c|c|c|c|c|c|c|c|c|}
\hline \multirow[t]{2}{*}{ a. } & $\begin{array}{l}\text { Ligirí máá } \\
\text { money } \mathrm{DEF}\end{array}$ & $\begin{array}{l}\text { bé } \\
\text { be.at }\end{array}$ & $\begin{array}{l}\grave{o} \\
\text { 3SG.P }\end{array}$ & OSS & \multicolumn{2}{|c|}{$\begin{array}{l}n u ́-z a ́ a ́ \\
\text { left-hand }\end{array}$} & $\begin{array}{l}n i ́ . \\
\text { inside }\end{array}$ & & \\
\hline & \multicolumn{8}{|c|}{ 'The money is in his/her left hand.' } & \\
\hline \multirow[t]{2}{*}{ b. } & $\begin{array}{l}\text { *nógálli } \\
\text { egg }\end{array}$ & $\begin{array}{l}\text { máá } \\
\mathrm{DEF}\end{array}$ & $\begin{array}{l}b e ́ \\
\text { be.at }\end{array}$ & $\begin{array}{l}\text { wàhú } \\
\text { snake }\end{array}$ & $\begin{array}{l}\text { máá } \\
\mathrm{DEF}\end{array}$ & \multicolumn{2}{|l|}{$\begin{array}{l}\text { pùùní } \\
\text { stomach }\end{array}$} & $\begin{array}{l}\text { ní. } \\
\text { inside }\end{array}$ & \\
\hline & \multicolumn{9}{|c|}{ Intended: 'The fowl egg is inside the stomach of the snake.' } \\
\hline \multirow[t]{2}{*}{ c. } & $\begin{array}{ll}\text { kpibi bé } & \text { lice be.at }\end{array}$ & $\begin{array}{l}\text { bíá } \\
\text { child }\end{array}$ & $\begin{array}{l}\text { máá } \\
\text { DEF }\end{array}$ & & $\begin{array}{l}\text { zúyù } \\
\text { head }\end{array}$ & $\begin{array}{l}\text { ní. } \\
\text { inside }\end{array}$ & & & \\
\hline & \multicolumn{9}{|c|}{ 'There are lice in the head of the child.' } \\
\hline d. & $\begin{array}{l}\text { *álikálímí } \\
\text { pen }\end{array}$ & $\begin{array}{l}\text { máá } \\
\mathrm{DEF}\end{array}$ & $\begin{array}{l}p a ́ \\
\text { lie on }\end{array}$ & $\begin{array}{l}\text { téébùlt } \\
\text { table }\end{array}$ & & $\begin{array}{l}\text { máá } \\
\mathrm{DEF}\end{array}$ & $\begin{array}{l}\text { gbùnni } \\
\text { front }\end{array}$ & & $\begin{array}{l}\text { ní. } \\
\text { inside }\end{array}$ \\
\hline e. & $\begin{array}{l}\text { Intended: 'The } \\
\text { nó-gállì } \\
\text { fowl-egg }\end{array}$ & $\begin{array}{l}\text { pen is } \\
\text { máá } \\
\text { DEF }\end{array}$ & $\begin{array}{l}\text { ing by } \\
b e ́ \\
\text { be.at }\end{array}$ & $\begin{array}{l}\text { he table } \\
\text { wàhú } \\
\text { snake }\end{array}$ & máá & $\begin{array}{l}\text { púlí } \\
\text { stomach }\end{array}$ & & $\begin{array}{l}\text { ní. } \\
\text { inside }\end{array}$ & \\
\hline
\end{tabular}

In addition to its function as a locative marker, it also has a deictic function and, in that context, it expresses the concept of 'there'. Thus, it also has a deictic of place function. I exemplify this in (8). However, the deictic function does not receive detailed consideration here since it is not the focus of this current paper.

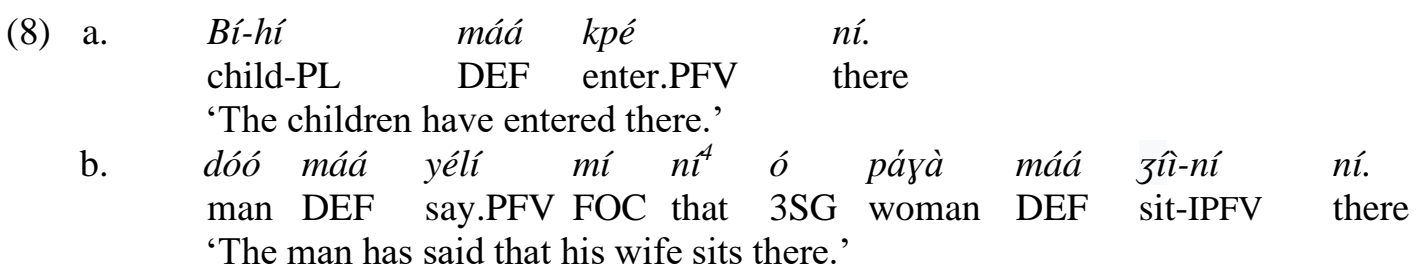

Having shown that the ni particle also has a place deictic function, the next sub-section that follows offers a systematic discussion on the use of body-part nouns in locative constructions.

\subsection{The use of body-part nouns in expressing spatial grammar}

As briefly pointed out earlier, the use of body-part terms in locative expressions is a prevalent feature of most African languages of which Dagbani is no exception. In the examples (9-10) that follow, we see instances from Dagbani in which the same word used to refer to a body part in the examples labelled (a) is also used in a locative construction as in the examples labelled (b) and (c). As already mentioned, in this paper I do not only give an account of the grammar of space in Dagbani but also argue that there are pieces of evidence in favour of setting up body nouns in locative constructions as postpositions instead of seeing them as nouns. For instance, I argue that these body-part nouns, when used in locative constructions, are syntactically and semantically distinct from nominal words. For instance, in glossing, when pùùni is glossed as 'stomach', it refers to a body part (nominal), but as 'inside', it becomes a postposition.

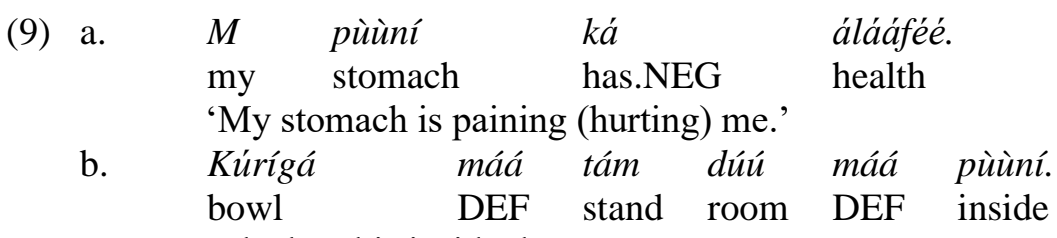

'The bowl is inside the room.'

\footnotetext{
${ }^{4}$ Note that the complementizer head ní is different from the general locative marker. The phonetic representation is really the -ATR vowel quality, but it is represented in orthography with the +ATR vowel quality.
} 


c. Nóó máá bé dúú máá pùuní.
fowl DEF be.at room, DEF inside
'The fowl is inside the room.'
(10) a. Bía máá zúyù bárí pám.
child DEF head be.big INT
'The child's head is very big.'
Bùkú máá pá téébúli máá zúyù.
book DEF be.on table DEF on (top of)
'The book is on the table.'
Bía máa 3í/*pá lá téébúlí máa zúyù.
child DEF sit/*lie FOC table DEF on (top of)
'The child is sitting on the table.'

In the data given in (9) and (10) above, the body-part terms, which occur as nouns in (9a \& 10a) have postpositional counterparts as seen in the sentences in $(9 \mathrm{~b} \& 10 \mathrm{~b})$. The forms however, remain the same even at the suprasegmental level, as there are no tonal differences. It is worth mentioning that in cases where these nouns are used to code spatial grammar (postpositions), there is also invariably a requirement for what has been termed posture verbs. As proposed by Talmy (2000) and Dixon (1991) inter alia, posture verbs are generally used to indicate the position of an object (be it animate or inanimate), labelled as FIGURE in relation to another entity that is known as GROUND. In the English language, verbs such as lie, stand and sit are classic examples of posture verbs. In the data in $(9 \mathrm{~b}, 10 \mathrm{~b})$, for instance, the NPs - kùrígá máá 'the bowl', bùkú máá 'the book' - constitute what we would call the FIGURE. There are also locative complements (which constitute object NPs and locative morphemes; here a postposition). It is important to mention that posture verbs are sensitive to the animacy of the FIGURE. This explains why in (11c), only zi 'sit on' can be allowed but not $p a$ ' 'lie on'. Atintono (2004) makes a similar observation for Gurenc posture verbs and accounted for this based on the assumption that sitting postures for animate and non-human NP references are viewed differently. ${ }^{5}$ The same thing is demonstrated in the data in (11) and (12) where we also observe that the body-part terms occur as nouns in (11a \& 12a) and then as postpositions in (11b \& 12b).

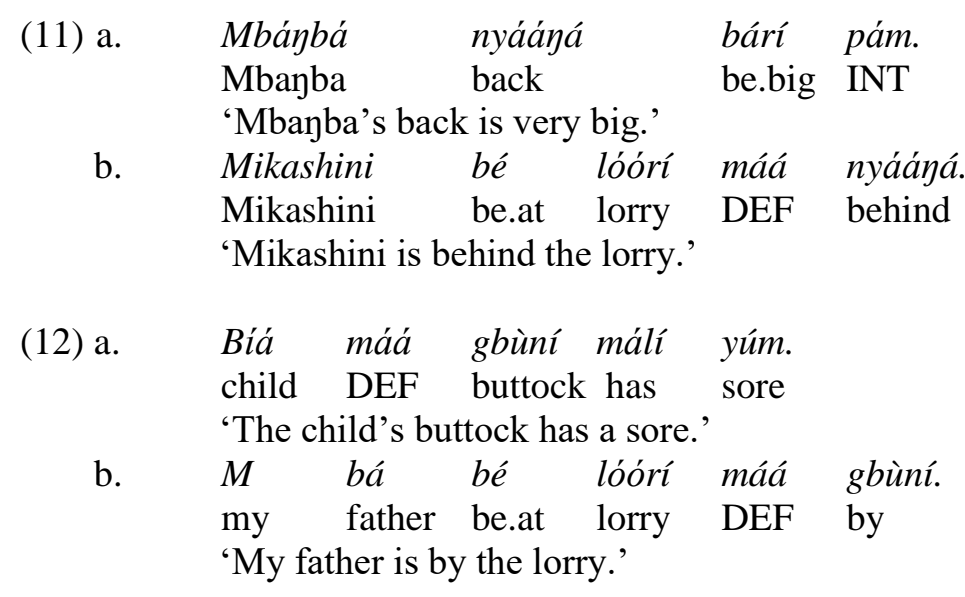

In these data, we observe that the words that are used as nominals are also used as postpositions as in (11b) and (12b) above. The postpositions seem to generally occur after locative verbs and mark the GROUND of the objects whose locations are being described. In the table that follows, I present the body-part terms in Dagbani, which are used both as body-part nouns and as postpositions.

\footnotetext{
${ }^{5}$ Readers may consult Schaefer and Egbokhare (2008) and references cited therein for similar conclusions drawn for Emai posture verb properties. I, however, do not pursue the semantics of posture verbs further, since that is beyond the scope of the current paper.
} 
Table 1. Nominal and postpositional meanings of body-part nouns

\begin{tabular}{|c|c|c|}
\hline $\begin{array}{l}\text { Body-part/landmark term } \\
\text { Zúyù }\end{array}$ & $\begin{array}{l}\text { Nominal meaning } \\
\text { head }\end{array}$ & $\begin{array}{l}\text { Postpositional meaning } \\
\text { on (top of) }\end{array}$ \\
\hline Pùlí (Pùùnî) & stomach & in (side) \\
\hline Gbùní (Gbùnní) & buttock & by, under, bottom \\
\hline Tòòní & front & ahead of \\
\hline Lùyùlí & side & beside \\
\hline Nùzáá & left hand & left hand side of \\
\hline Nùdírígú & right hand & right hand side of \\
\hline Nyààyá & back & behind \\
\hline Tìná & land, ground, inhabited place & down \\
\hline Zúyùsááa & top & above \\
\hline Lónní & throat & in (enclosed) \\
\hline
\end{tabular}

Presented in table 1 is a comprehensive list of Dagbani postpositions that originate from nouns. Note that these body-part/landscape terms, which express "spatial relations" in Dagbani have the same suprasegmental features as their noun counterparts. As I will show later in Dagbani, they however have different morphological and syntactic characteristics from the nouns, and that motivates the argument that these morphemes are better analysed as a distinct grammatical class although they are diachronically derived from nouns. In my account, I contend that pùlí simply means stomach and pùùní has two meanings: (1) an adposition, meaning an enclosed location (generally) and (2) the stomach as an internal organ when it refers to the human being. Therefore, the ní in pùùní is the same ní in pùlí $n i$. The difference between them is that pùùní is a postposition, whereas pùlí ní is a noun followed by a locative. This explains why we could replace pùlí ní (13a) with pùùní in (13b) and the meaning will change slightly to anywhere inside the snake, not necessarily the stomach. Note that (6e) is what is repeated here as (13a) for convenience.

$\begin{array}{lllll}\text { (13) a. nógálli } & \text { máá bé wàhú máá pùli } & \text { ní. } \\ & \text { egg } & \text { DEF be.at snake DEF stomach } & \text { inside } \\ \text { 'The fowl egg is inside the stomach of the snake.' } & \\ \text { b. nógálli } & \text { máa bé wàh máa pùní. } & \\ & \text { egg } & \text { DEF be.at snake DEF inside } & \end{array}$

Olawsky (1999, p. 25) offers a similar account according to which the postpositions that are composed of NP+ni as in sani and lónní are really composed on sa 'there' and lón 'throat' and the postpositional locative marker ' $n i ́$ '. The nominal gbùní 'buttock' can have two different postpositional interpretations, though with a slightly different morphological make-up. In my analysis, gbùní literally means buttock, whereas gbùnní means 'in the buttock' (derived from gbùní and ní). That is, a combination of gbùní and the general locative marker ní. Thus, gbùnní literally means the location between the two buttocks (anus). I thus, propose that the two locative markers gbùní 'by' and gbùnní 'under' be separate postpositions, and not one. For instance, gbùní can be used to describe the location of an object that is located by the wheel of a car or anywhere very close to the car and very visible. It will be the equivalent of the sentence the ball is by the car. However, gbùnni cannot be used in that context. It can be used only when the ball is between the four wheels. It encodes the meaning under. $^{7}$ I call it a complex morpheme because two different morphemes constitute it. The differences in sentences (14) and (15) illustrate this fact.

\footnotetext{
${ }^{6}$ The term/word zúyùsáá is morphologically complex, made up of zúyù 'above' and sáá 'rain'. I need to point out here that zúyùsáá derives a kind of exocentric compound where the meaning of the compound has no relation to the meaning of the individual words.

${ }^{7} \mathrm{I}$ am grateful to an anonymous reviewer for pointing out this to me.
} 
(14) a.

Búkù dó téébúlí máá gbùnní. book lie table DEF under

'A book is lying under the table.'
b.
Bá-bílá bé kúyù-sí
dog-DIM be.at chair-PL
máá
DEF under

'There is a puppy under the chairs.'

(15) a

\begin{tabular}{|c|c|c|c|c|c|c|c|}
\hline $\begin{array}{l}\text { Bí-hí } \\
\text { child-PL }\end{array}$ & $\begin{array}{l}\text { máá } \\
\text { DEF }\end{array}$ & $\begin{array}{l}\text { bé } \\
\text { be.at }\end{array}$ & $\begin{array}{l}\text { kúyù } \\
\text { chair }\end{array}$ & $\begin{array}{l}\text { máá } \\
\text { DEF }\end{array}$ & $\begin{array}{l}\text { gbùní. } \\
\text { by }\end{array}$ & & \\
\hline \multicolumn{8}{|c|}{ 'The children are by the tree.' } \\
\hline álíkálìmí & máá & dó & & lá & téébúlí & máá & gbùní. \\
\hline & $\mathrm{DEF}$ & lie do & & FOC & table & DEF & by \\
\hline
\end{tabular}

It is also possible for the concept of 'under' to be expressed in Dagbani using the morpheme loy, 'throat', plus the locative morpheme ní. This is illustrated in (16).
(16) a.
Bía máá dó
child DEF lie d
dó téébúlí máá
lónní
'The child is lying down under the table.'

$\begin{array}{llllll}\text { b. } & \text { Bá-bílá kúá dó lónní kpè há } & \text { há } \\ \text { dog-DIM } & \mathrm{DEF} \text { lie down (on) chair under here } & \text { DM } \\ \text { 'The puppy is lying down under the chair over there.' } & & \end{array}$

In the section that follows, I investigate the syntactic category of these nouns that are used as postpositions in expressing spatial locations.

\subsection{Establishing the categorical status of body-part nouns in locative constructions}

This section spells out exactly what the distinction between nouns and these so-called postpositions are in Dagbani. I outline some semantic, morphological and syntactic criteria that are attributable to nouns but not to these postpositions. I interpret these differences in their syntactic, morphological and semantic properties to mean that they are distinct word classes in the language.

In the first place, notice the unacceptability of PostPs (occurring with adjectives and determiners) $(17 \mathrm{~b}, 17 \mathrm{~d})$ for adjectives and determiners respectively. This is in contrast with their noun counterparts in $(17 \mathrm{a}, 17 \mathrm{c})$, where occurrence with adjectives and determiners are allowed. This syntactic pattern further serves as an argument for distinguishing between PostPs on the one hand and NPs on the other.

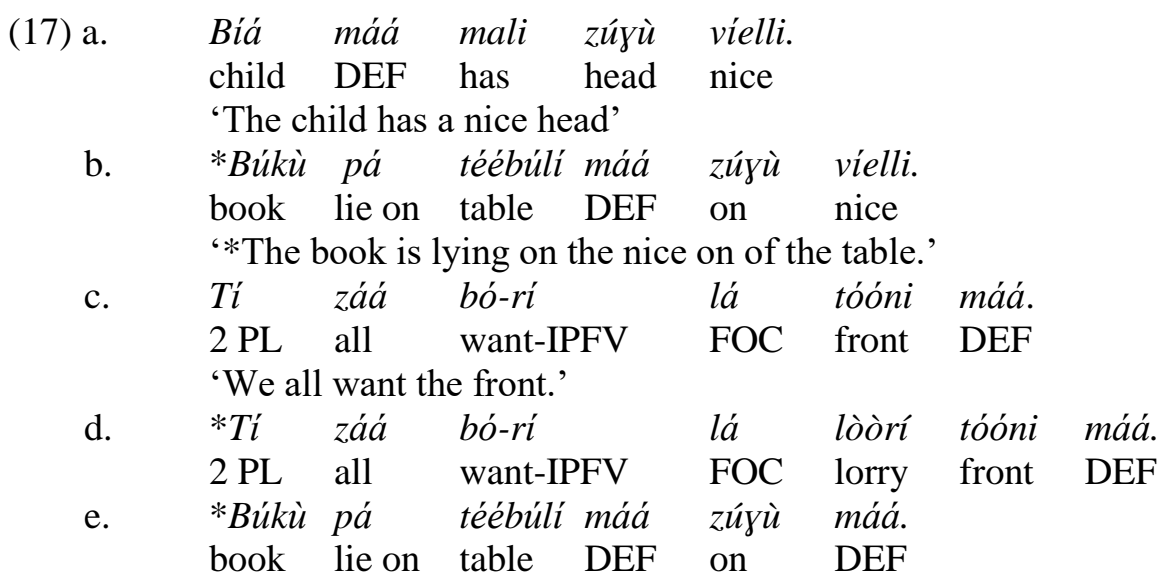

Thus, whereas NPs are compatible with modifying categories as in the grammatical sentences in (17a) and (17c), the body-part nouns that occur in spatial constructions are banned from occurring with this category of functional words. This is evident in the incompatibility between body-part in locative 
constructions and determiners; such a syntactic rule does not apply to Dagbani body-part nouns that occur in location constructions since they are postpositions.

Another syntactic distinction between nouns and the body-part nouns that occur in locative constructions is their distinct distributional property with intransitive verbs. Of revealing significance is the fact that whereas the intransitive verb is compatible with a postposition on its own, it is not possible for the same intransitive verb to be followed by any other noun. Cross-linguistically, intransitive verbs do not accept complements syntactically (except with cognate objects). This implies that apart from cognate objects, it is wrong to assign an intransitive verb a complement. A popular example of a cognate object occurring with an intransitive verb is 'I sing a song'. Though they do not need a complement, they allow postpositional adjunction. I illustrate this in the grammaticality of (18a) versus the ungrammaticality of (18b).

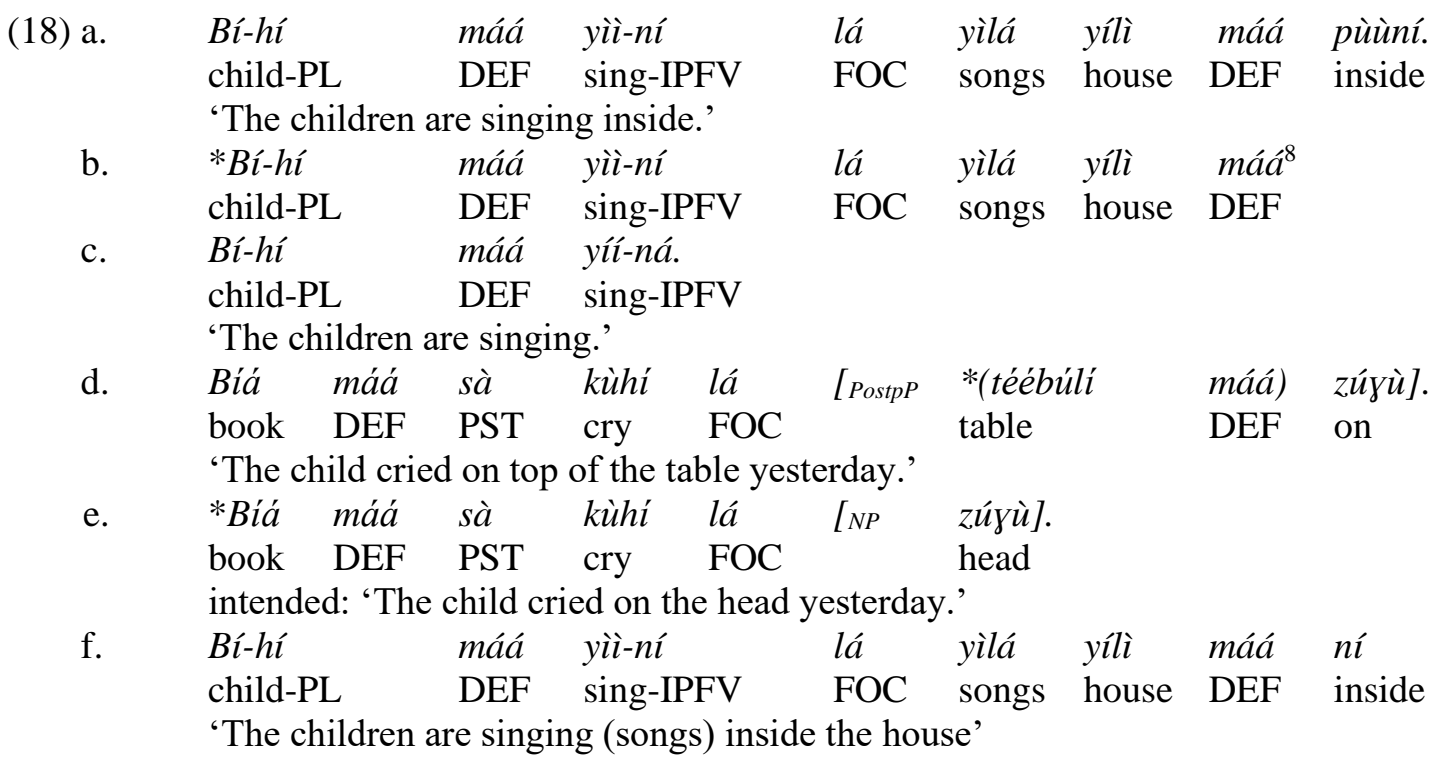

Thus, in Dagbani, whereas postpositions are allowed in the postverbal position of intransitive verbs, nouns are disallowed in this position.

Another piece of syntactic evidence that this paper uses in favour of the author's argument that bodypart terms as postpositions are distinct from nouns is c-selection of verbs. The concept of c(ategory)selection is the idea that by virtue of their inherent semantic properties, certain grammatical categories have to co-occur with words of certain grammatical classes. In this part, I use the c(ategory)-selection requirement of locative verbs in Dagbani to buttress my proposal that these body-part nouns used as postpositions be distinguished from nominal items. By this argument, the grammaticality of sentences (19b) and (20b) and the ungrammaticality of (19c) and (20c) is an indicator that dúú máá pùùní, '(in) side the room', téébúli máá zúyù 'on top of the table', dúu máá 'the room', and téébúli máá 'the table', are not the same syntactic categories.

$\begin{array}{ll}\text { (19) a. } & \text { *Búá máá bé } \\ \text { b. } & \text { goat DEF be.at } \\ & \text { gúá máá bé dúu máa pùuní. } \\ \text { goat DEF be.at room DEF inside } \\ \text { 'The goat is inside the room.' } \\ \text { *Búa máa be dúu máá. } \\ \text { goat DEF be.at room DEF } \\ \text { Intended: 'The goat is inside the room.' }\end{array}$

\footnotetext{
${ }^{8}$ It is worth noting that it is possible to use only ní to make this sentence grammatical, and this is evident in the grammatical version of (18b) which I present in (18f).
} 


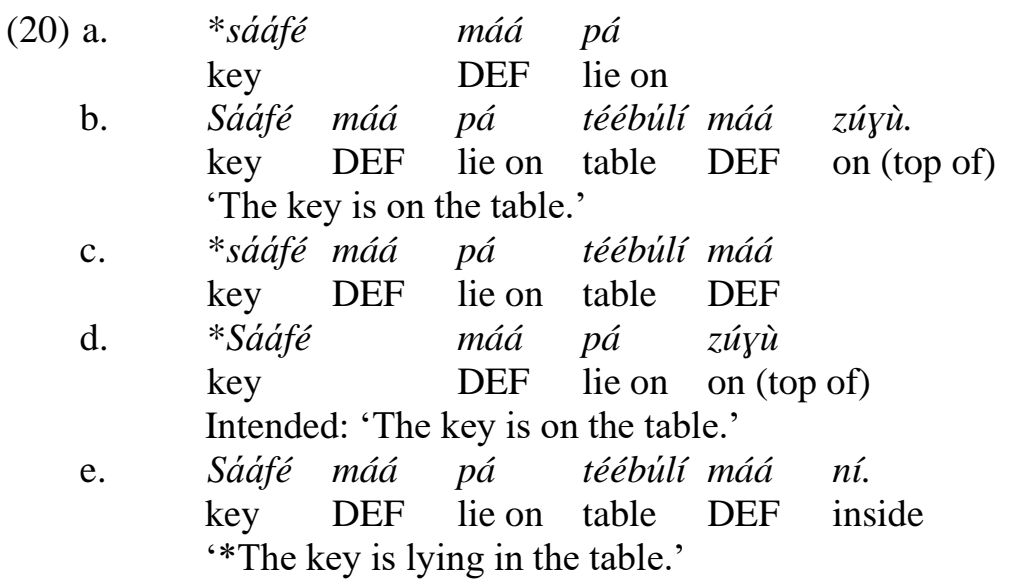

In line with the syntactic argument put forth, the assumption is that Dagbani locative verbs syntactically c-select postpositions (see Atintono, 2004 for a similar proposal for Gurene, a genetically related Mabia language). With this assumption, the ungrammaticality of (19a) and (20a) is attributable to the use of the locative verbs bé and pá, meaning 'to be at' and 'to lie on top of' respectively, without postpositions following them which are required to show the GROUND. Thus, the grammaticality of $(19 b, 20 b)$ and the ungrammatically of (19a, 19c, 20a, 20c) is ascribed to the fact that the Dagbani locative verbs always require a postposition and not a noun. The locative verbs so far identified in Dagbani are $d o ́$ ' to lie down on', $p a$ ' to lie on top of', bé 'to be at', and $k a^{9}$ 'not be at'. It is also worth pointing out that the ungrammaticality of (20e) is borne out of the fact that $n \hat{i}$ 'inside' and zúyù 'on (top of)' are not in free variation and for that matter one cannot be substituted for the other. If they were the same, then (20e) would have been grammatical, contrary to the empirical material available. The order of the locative construction of Dagbani is proposed as it is in (21).

\section{(21) [NP FIGURE $_{\text {[ }}\left[\right.$ PPOSITIONAL $\left.\left.\left[\mathrm{NP}_{\text {GROUND }}[\mathrm{PP}]\right]\right]\right]$}

The positional verb (VP ${ }_{\mathrm{Pos}}$ ) slot can be filled by any of the positional verbs $z a$ 'stand', pá 'lie on', dó 'lie down' among others. Note that the selection of the positional verb depends on the relation between figure and ground: I contend that the syntactic slot of the subject-noun phrase position is filled invariably with a figure. The figure is followed by a locative verb, which is then followed by another NP (the ground) and then the postpositional phrase (PP).

Another distinct syntactic characteristic of PPs and NPs in Dagbani is the fact that whereas there is a ban on stranding postpositions (22a, 22b), NPs can be stranded as illustrated in (23).

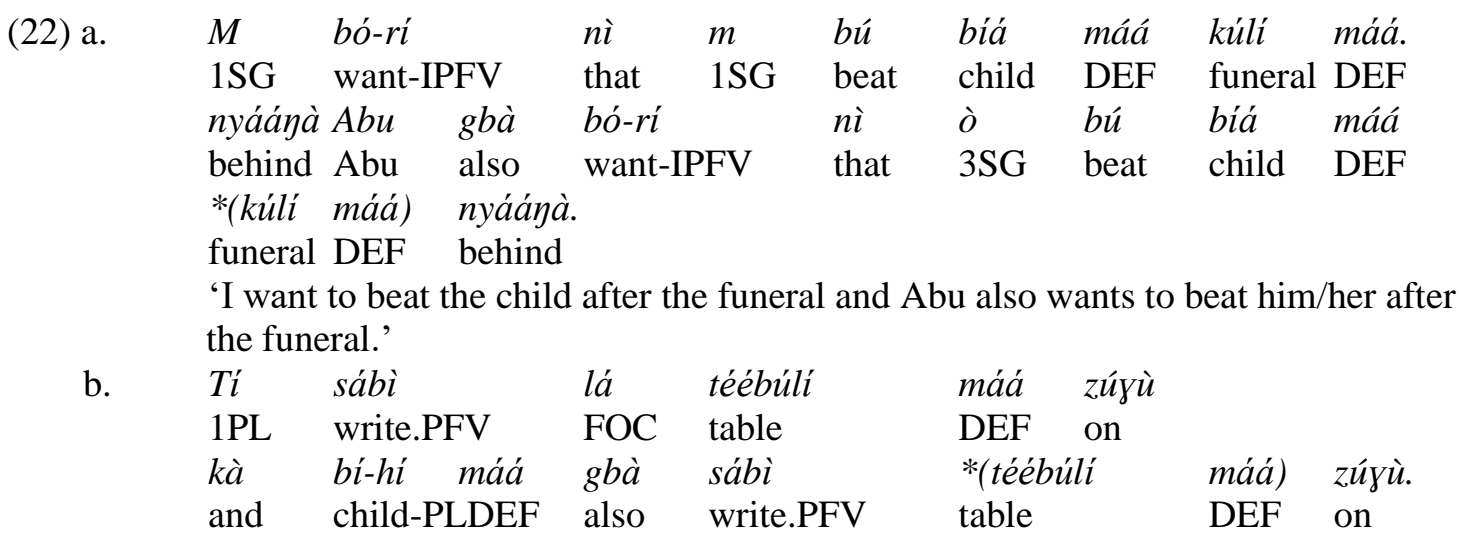

'I have written on the table and the children have also written on the table.'

\footnotetext{
9 For now, I assume, pending future investigation that the negative verb ká 'not be at' is the same as the one in example (9a) that is glossed as has.NEG,
} 
In contrast to this ban on stranding of postpositions in Dagbani as exemplified in (22) is the fact that Dagbani allows stranding of NPs in contexts that are parallel to (22) as illustrated in (23).

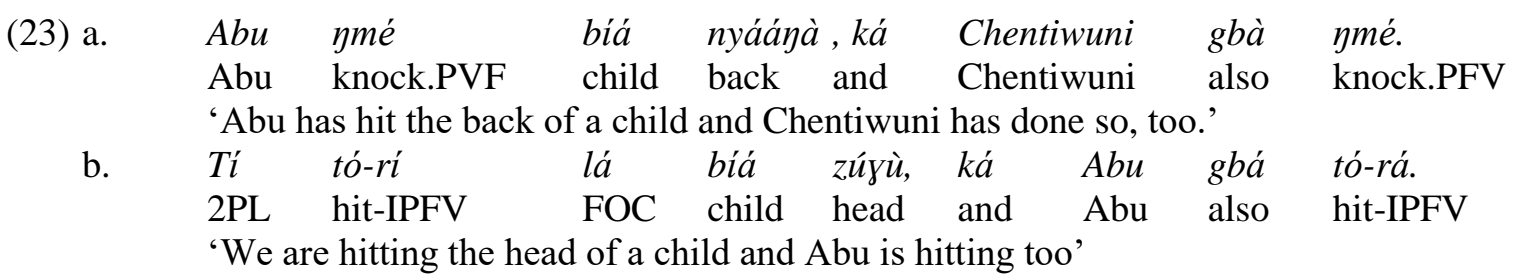

Note that the unacceptability of postpositional stranding as shown in (22) and the fact that the NPs variants can be stranded in (23) will naturally present a problem for any assumption that the two are the same in their distribution.

Apart from the above syntactic evidence, there is also semantic evidence, which suggests that these nominal items used in spatial grams are analysable as postpositions rather than as nouns. Metaphorically, I contend that when Object 1 is located on Object 2, then the former could be said to be located on (the head of) the latter. As conventionally done in the study of spatial/relationship grammar, I would henceforth refer to the two objects that are involved in a given locative relationship as the FIGURE and GROUND. Following current trends in spatial grammar literature - Talmy, 1983, Langacker, 1986; and Svorou, 1993 - I see the FIGURE as the object that is located in relation to another object, referred to as the GROUND. For instance, in a sentence like bía máá bé lóóri máá pùùní (that is, 'the child is in the car'), bía máá (that is, 'the child') is the figure and lóorí máá ('the car') is the ground.

I opine that whenever these body-part nouns occur in spatial constructions, they functionally show location with reference to a figure and the ground. In languages, the expression of location is generally a property of pre/postpositions and not nouns. These body-part nouns in locative constructions therefore show location semantically. Accordingly, it would not be appropriate to assign them the nominal class of words. On this semantic ground, I argue that body-part nouns in locative constructions are semantically postpositions and not nouns.

On the semantic features of postpositions, I suggest, following postulations in Fillmore (1982) and Leech (1974), that the region of the landmark of locating objects may be expressed in terms of "a system of coordinates" comprising top and bottom (vertical axis), left and right and back and front, that is, horizontal axis. For instance, the two poles of the vertical axis or top bottom are zúyù, that is, 'top, surface', and gbùní 'by', and gbùnní 'bottom, under'. Examples of these are:

(24) a. Fúrilá bé lóóri máá zúyù lantern be.at lorry DEF on (top of) 'There is a lantern on (top of) the lorry.'

$\begin{array}{lllll}\text { b. } & \text { Bí-hí } & \text { maa } & \text { zíi-ní } & \text { tía máá gbùnní } \\ \text { child-PL } & \text { DEF sit-IPFV } & \text { tree } & \text { DEF } & \text { under }\end{array}$

'The children sit under the tree.'

The locations expressed by zúyù 'top', and gbùnní 'under', are vertically related spatially. As pointed out by Boadi (2010, p. 232) for the Akan equivalents of these vertical poles, $\varepsilon s o$ 'top'/ 'surface', and asee 'bottom' / 'under part', there is an absolute semantic boundary between the two, and accordingly, the two never overlap in their semantic specifications except for the fact that they are both designated for the semantic feature [+spatial]. Owing to this absolute semantic boundary between the two, it is not possible for an object to be located at both poles of the axis simultaneously. This explains why there is an inherent contradiction in the sentence (25) where the grammatical subjects of the two clauses are intended to be co-referentials, as similarly suggested by Boadi (2010, p. 232) in his Akan analysis of the semantic features of postpositions. 


\begin{tabular}{llllll} 
*fúrìlá & & máá & bé téébúlí máá & zúyù \\
lantern & & DEF & be.at table & DEF & on \\
$k a ̀$ & $b e ́$ & $d i ́$ & gbùnní gbá & & \\
CONJ be.at & 3SG & \multicolumn{2}{l}{ under also } & &
\end{tabular}

Intended: 'The lantern is on the table and also under the table.'

As already pointed out above, another spatial relation expressed by postpositions is the horizontal axis also called the front-back. Accordingly, a speaker as being located on the nyààyá 'back' of another entity may view an entity. This area, as has been suggested by researchers on a similar phenomenon in different languages (Boadi, 2010 for Akan, Saanchi, 2003 for Dagaare), lies on the same horizontal axis as its front location, tòoní, and the two locations are separated by the body which provides the point of reference (cf, Boadi, 2010). Just as was observed for gbùní 'by', gbùnnì 'under, bottom', and zúyù 'on top of', the relationship between tòòní 'front', and nyààya 'back', is that of converseness. Examples of the use of the horizontal axis include: ${ }^{10}$

(26) a. Mikáshiní dó tía má nyààná.
Mikashini lie tree DEF behind
'Mikashini is lying behind the tree.'
b. Mikáshiní dó tía máá tòoní.
Mikashini lie tree DEF in front (of)
'Mikashini is lying in front of the tree.'

Finally, the top-bottom (vertical) and front-back (horizontal) axes and the morphemes that are used to encode them, zúxù, gbúnnì, tòòní and nyààyá, can be paralleled by a third opposition, right-left. The postpositions nùzáá 'left', and nùdírìgú 'right', are used to denote these poles of the axis. They however, refer to the opposite poles of this left-right axis of the directional system. I illustrate this claim with the following examples:

(27) a. Vikùbá zí lá Chéntíwúní nùzáá.
Vikuba sit FOC Chentiwuni left hand side of
'Vikuba is sitting on the left side of Chentiwuni.'
b. Vikùbá zí lá Chéntíwúní nùdírìú.
Vikuba sit FOC Chentiwuni right hand side of
'Vikuba is sitting on the right side of Chentiwuni.'

The semantic relationship between nùzáá and nùdírìgú is one of converseness as observed on the vertical and horizontal axes.

From a morphological point of view, there is also evidence that suggests that body-part terms used in locative constructions are not nouns and should thus be analysed as postpositions. Morphologically, count nouns of Dagbani make a distinction between singular and plural nouns (Yahaya, 1979; Olawsky, 1999, 2004, Hudu, 2005) among others. These body-part nouns in spatial constructions, however, cannot inflect for plurality. This claim is buttressed in the grammaticality of sentences (28a) and (29a) versus the ungrammaticality of (28b) and (29b). This seems to suggest that if these body-part nouns were analysable as nouns and not grammaticalized as postpositions, then they should have been able to possess this morphological feature of creating a distinction between singular and plural forms. This leads to my conclusion that when nouns are used to code spatial grammars, they do not inflect for number.

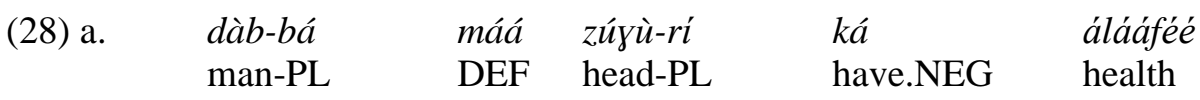

'The men's heads are not very healthy' (something is wrong with heads of the men.)

\footnotetext{
${ }^{10}$ There is also the possibility of the speaker or focal participant being the point of reference, leading to the ambiguity that tóóni can mean 'beyond'
} 

b. *bùkú-nìmá
máá pá
téébúlí-nìmá
máá
zúyù-rí
book-PL
DEF lie on table-PL
DEF
on-PL

'*The books are ons the tables.'

(29) a.

$\begin{array}{llll}\text { Dàb-bà } & \text { gbùn-á } & \text { bí } & \text { bárà } \\ \text { Man-PL } & \text { buttock-PL } & \text { NEG } & \text { be big }\end{array}$

'The buttocks of men are not big.'

b. *óóri-nìmá máá bé tí-hí máá gbùn-à
lorry-PL DEF be.at tree-PL DEF under-PL
'*The lorries are unders the trees.'

We see from the above discussion that these postpositions behave differently from the nouns from which they probably developed diachronically. Despite the fact that these body-part terms used in spatial constructions might have evolved from the nominal category, I contend that analysing them as postpositions in the language offers a better linguistic characterization of this class of words. Based on the differences between them and their phonetically identical nouns, I suggest that they are a distinct lexical category from the nouns. A crucial assumption here is that the items that occur in locative constructions have lost their nominal properties via the grammaticalizations and now function as functional words, the reason for which they cannot inflect for number. I conceive grammaticalization as a change in language, which involves the development of functional morphemes/words from existing lexical forms (cf Hopper and Traugott, 2003; Heine et al., 1991; Hopper, 1991). Thus, unlike Akan where Osam et al. (2011, p. 112) note that "the so-called postpositions (SCPs) display syntactic properties akin to nouns in the language", in the case of Dagbani, grammaticalization results in the exhibition of different morphology between the nominals in spatial constructions and their noun counterparts. In the section that follows, I outline these proposed grammaticalization phenomena for the development of body-part and landmark terms in locative constructions.

Before I show how these body-part nouns are used in locative constructions, I consider the fact that it might be a good idea to add a schematic picture of a human body, showing the body-part names, before illustrating how the transferred usage is comparable in the next section. This is shown in Figure 1.

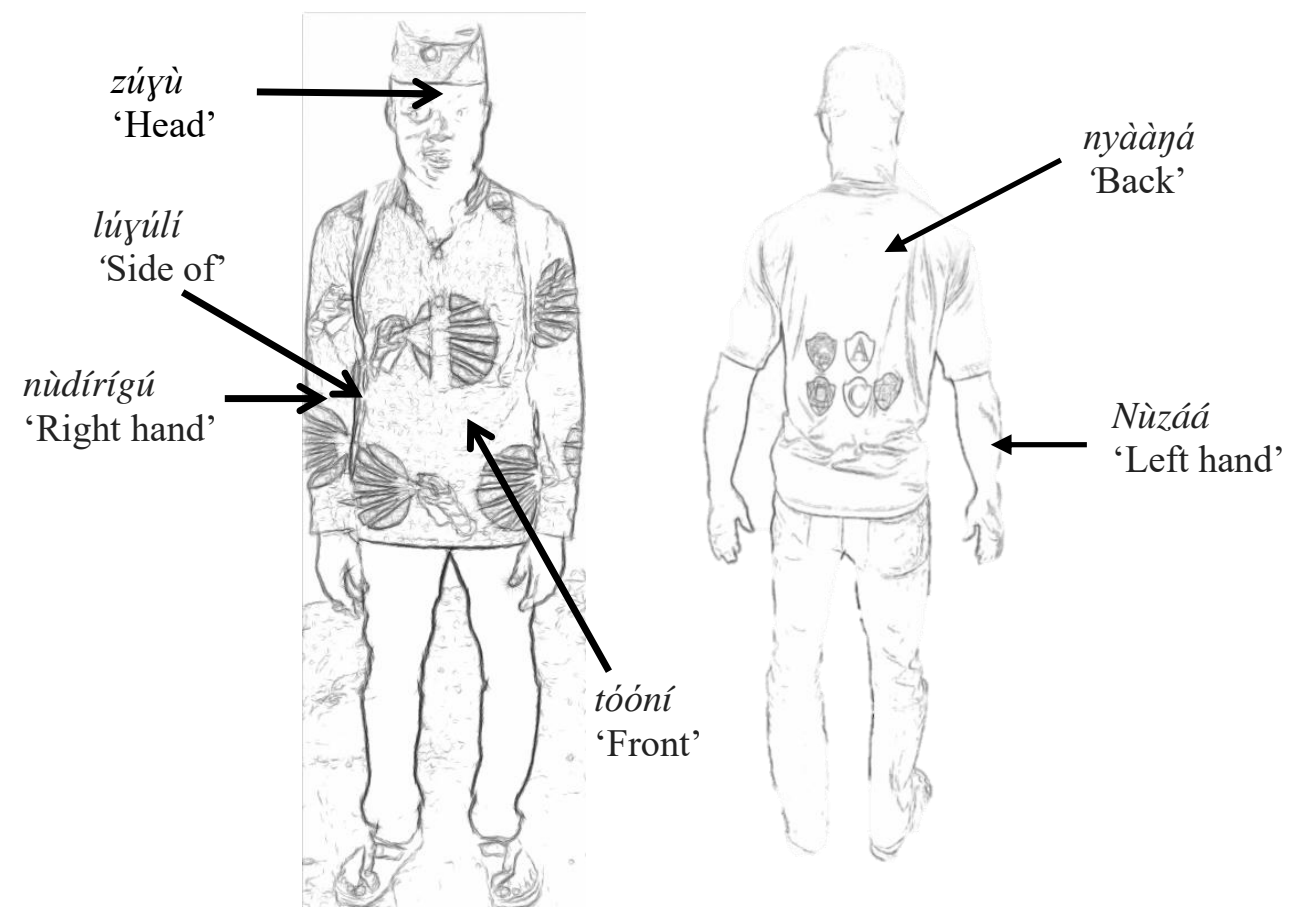

Figure 1. Schematic picture of a human body

Source: Free-hand sketched 
In this sub-section, I considered some syntactic processes that take place in Dagbani and how they can target the different nouns on one hand and body-part nominal in location constructions on the other. I employed syntactic, semantic and morphological criteria to support my proposal that nouns are distinct from postpositions, although the latter developed from the former. The fact that these two-word classes exhibit distinct morphosyntactic characteristics motivates my assumption that they constitute different word classes in Dagbani. In the next section, I give an account of a proposal seeking to explain how these body-part nouns are used in locative constructions, proposing metaphorical extensions of nominal meanings and metonymic extensions.

\section{Development of body-part postpositions}

This section of the paper attempts to give an account of the development of body-part nouns into postpositions. From a synchronic perspective, I maintain that the use of body-part nouns as postpositions could be accounted for using semantic change. Although body-part postpositions may come from lexical morphemes referring to certain body-parts, I advance the claim that since they develop into functional morphemes via metonymic and metaphorical extensions through usage, they should be analysed as postpositions. In line with postulations in Hollenbach (1995), I place the meaning of body-part nouns of Dagbani into three categories: the basic meanings, meanings derived via "space projection" extension, and meanings generated via metaphorical extensions. I postulate in this paper that the basic meaning usually belongs to the content or lexical class of nouns, whilst the last two have to do with the postpositional functions of these body-part nouns. Thus, when they occur in postpositional phrases, they become heads of the postpositional category. In this paper, I adopt Hollenbach's proposal in discussing the development of body-part nouns in Dagbani. Adopting this model is borne out of the fact that with this model Hollenbach (1995) is able to account for the nominal and postpositional meaning of body-part nouns in Mixtecan. It is my assumption that this will be equally helpful in accounting for the similarities or differences that may exist between body-part postpositions and their heterosemic noun counterparts. As mentioned briefly earlier in this paper, one main property of these morphemes that encode spatial relations is the fact that they are derived from noun sources including body-parts and landmarks. Notwithstanding their origin from nominal words, their syntactic, morphological and semantic characteristics are distinct from nouns as shown earlier.

\subsection{Metaphorical extensions of nominal meanings}

I propose that the other nominal meanings for Dagbani body-part nouns in postpositional phrases may be generated from metaphorical extensions. From this point of view, the human body-parts extend to non-human beings such that cars could have stomachs, anuses, sides, and heads among others. This reason is what the paper assumes could be responsible for the current use of these body-part nouns in postpositional phrases in the language. ${ }^{11}$ I illustrate this in Figure 2.

\footnotetext{
${ }^{11}$ A reviewer drew my attention to the fact that Dagbani is not that different from other languages like English when it comes to these metaphorical extensions, since when we consider the nose, belly, wings and tail of an aircraft we can see the extension of the body-parts of a bird to an aircraft.
} 


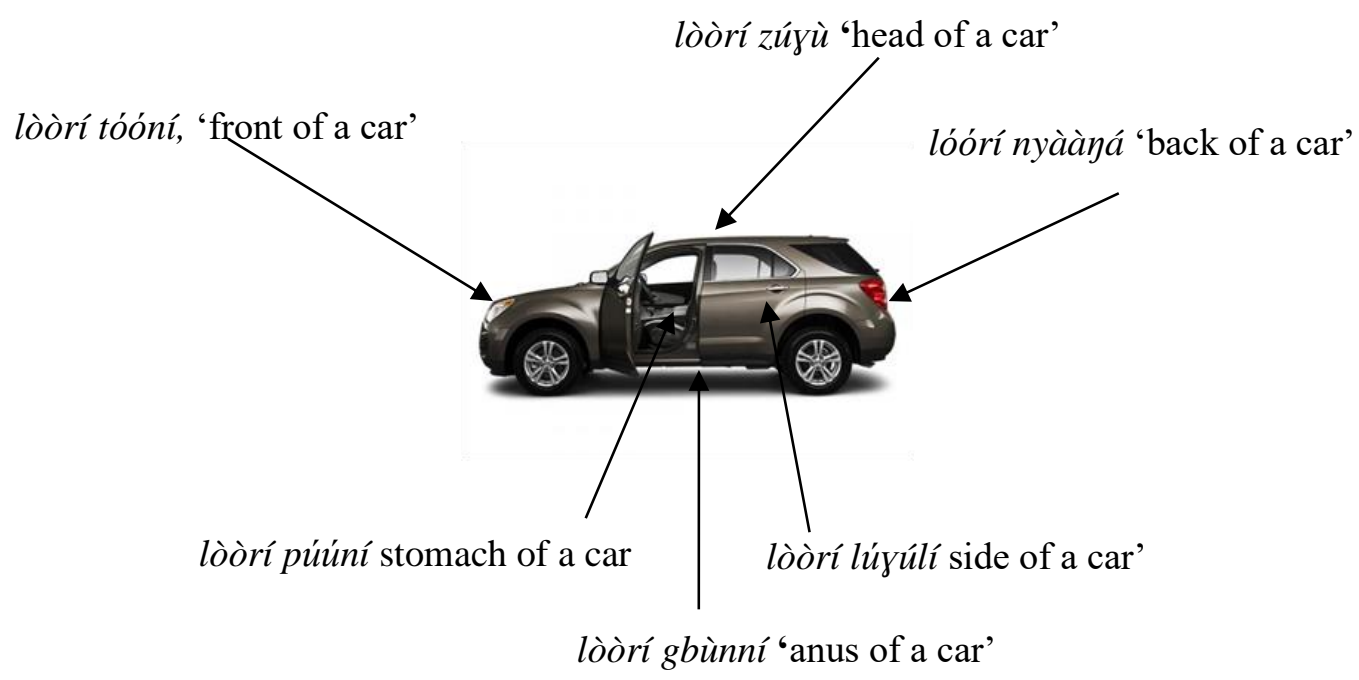

Figure 2. A car illustrating a metaphorical extension of body-part nouns

Source: Camera shot

\subsection{Metonymic extensions}

In addition to the above on metaphorical extensions of nominal meanings, I also suggest that the metonymic extensions of projection of space as illustrated in Figure 1 could be useful in accounting for the postpositional functions of the body-parts in Dagbani locative constructions. By this, my argument is that the projection of space extends the meanings of these body-part nouns from just the part of the object that is denoted to the area that is assumed to be "projected" by that part of the body. This, I argue, is an issue of metonymic extension. Hollenbach (1995, p. 171) defines metonymy as the use of a word for something associated with its original meaning. For instance, the basic meaning denoted by zúyù is 'head'. However, because of projecting space extension, it could also mean the area/part of space that is at the top, and zúyù has consequently undergone a metonymic extension to mean 'on top of.' The meaning would then undergo projection of space extension to an extent that zúyù 'head' could be used to refer to the area above the top of something, that is any area projected from the top of, for instance, a car as in Figure 3.

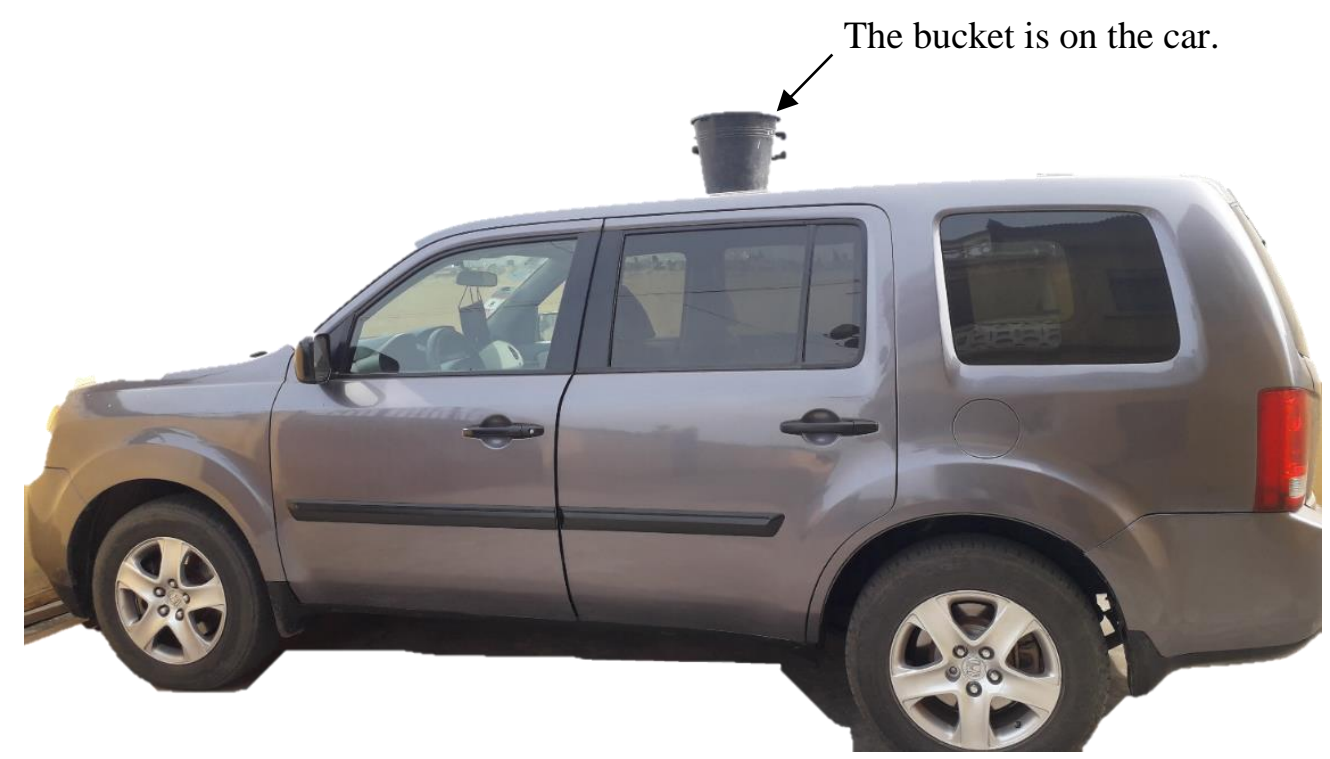

Figure 3. A picture of a car illustrating the expression of the location "on"

Source: Camera shot 
When body-part nouns get metonymic extensions, they lose their nominal properties and become postpositions. They therefore tend to denote some axial path or region of objects, although diachronically they have evolved from body-part nouns. Ameka (2003, p.57) asserts that in such a context, "syntactically, the postpositions are bound elements that occur juxtaposed to NPs postnominally. That is, they cannot be stranded nor can they occur on their own as clausal arguments without a dependent nominal, even if it is a null pronoun." Osam et al. (2011), however, uphold that for a language like Akan, nouns that have been grammaticalized as spatial grams should not be called postpositions, but rather be analysed as relator nouns, since they display morpho-syntactic features that are typical of nouns.

\section{Conclusions}

This paper has given an account of the spatial and locative system in Dagbani. I have demonstrated that the expression of spatial grammar in Dagbani as shown for most other Ghanaian languages employs the use of body-part nouns, which are grammaticalized into postpositions. I have demonstrated that although body-part nouns used in locative constructions and some nominal items seem to cluster together in being identical in shape and share the same tonal features, their morpho-syntactic and semantic characteristics point to some dissimilarities between the nominal words and these body-part nouns that occur in locative constructions. I used syntactic parameters such as $\mathrm{c}$ (ategory)-selection of locative verbs and adjunction with intransitive sentences to make a tentative proposal that setting up body-part nouns as postpositions in locative constructions would help account for them better within the syntax of Dagbani. Morphologically, I demonstrated that these body-part terms in locative constructions differ from nouns, and so they should be set up as distinct from the nominals from which they might have evolved synchronically. On the development of these body-part nouns as postpositions, I assume that one can account for the syntactic and semantic development of body-part nouns into postpositions by employing grammaticalization, metaphorical extensions and metonymic extensions. The paper concludes that the body-part terms used in spatial and locative constructions have their basic meanings as nouns, but that their locative meanings are derived through metaphorical extensions and metonymic extensions. The paper is relevant because it establishes a new generalization concerning the categorical status of nouns and body-part locatives.

\section{Acknowledgement}

This paper is an expansion of a paper I presented during the Linguistics Association of Ghana (LAG) conference held at the University of Ghana in August 2010. I would like to thank the audience for questions and discussions. I am especially grateful to Felix Ameka for his insightful comments. I also acknowledge Shen Zheng and Mary Amaechi for useful discussion on the content of this paper and am particularly grateful to Mary Amaechi for painstakingly reading the entire manuscript and offering very insightful comments/suggestions. Thanks also to Tony Naden for checking the manuscript for language. Finally, I am indebted to the two anonymous reviewers of Topics in Linguistics for their critical comments, which I have duly implemented. I am also grateful to Jones Dandy Appawu of the Department of Mathematic Education, University of Education, Winneba and Jackson Jessel Agbi for their IT support in managing the camera-short images used in this paper. All analytical errors, however, remain mine.

Abbreviations used in this paper include, 1, 2, 3 for first, second and third person respectively, ADJUN=adjunct, AUX=auxiliary verb, $C O N D=$ conditional, $\mathrm{DM}=$ distal deictic marker, $\mathrm{DEF}=$ definite, $\mathrm{DIM}=$ diminutive

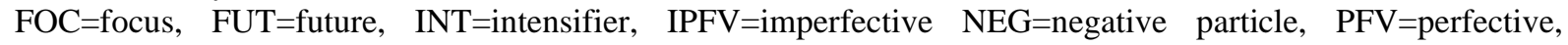
$\mathrm{PL}=$ plural, $\mathrm{POS}=$ positional, $\mathrm{PP}=$ postpositional phrase, $\mathrm{SG}=$ singular, $\mathrm{LOC}=$ locative particle.

\section{References}

Abubakari, H., 2018. Aspects of Kusaal grammar: The syntax-information structure interface. $\mathrm{PhD}$ Dissertation, African Studies Department: University of Vienna.

Ameka, F. K., 1995. The linguistic construction of space in Ewe. Cognitive Linguistics, vol. 6, pp. 139181. 
Ameka, F. K., 2003. Prepositions and postpositions in Ewe (Gbe). In: Typologie des Langues D'Afrique and Universaux De la Grammaire vol. II Benue-Kwa, Wolof. pp. 41-67.

Ameka, F. K. and Essegbey, J., 2006. Elements of the grammar of space. In: S. C. Levinson and D. P. Wilkins, eds. Grammars of space. Cambridge: Cambridge University Press.

Ameka, F. K. and Levinson S. C., 2007. The typology and semantics of locative predicates: posturals, positionals, and other beasts. Linguistics, vol. 45, no.5/6, pp. 847-871.

Atintono, A. S., 2013. The semantics and grammar of positional verbs in Gurene: A typological perspective. $\mathrm{PhD}$ Dissertation, University of Manchester, UK.

Atintono, S. A., 2004. The syntax and semantics of Gurenc posture verbs. Studies in the Languages of the Volta Basin II, pp.10-18.

Atintono, S. A., 2012a. The basic locative construction in Gurene. In: Proceedings of $6^{\text {th }}$ World Congress of African Languages (WOCAL6), pp. 337-348.

Atintono, S. A., 2012b. Basic and extended locative uses of posture verbs in Gurene. CogniTextes, vol. 7, http://cognitextes.revues.org/501, pp. 1-27.

Balmer, W. T. and Grant, F. C., 1929. A grammar of the Fante-Akan language. London: Atlantic Press.

Boadi, L. A., 2010. The Akan noun phrase, its structure and meaning. Accra: Black Mask Ltd.

Boadi, L. A., 1992. Locating objects and events in space. Linguistics Association of Ghana Conference paper, Legon.

Bodomo, A. B., 1994. Language, culture, and history in northern Ghana: An introduction to the Mabia linguistic group. Nordic Journal of African Studies, vol. 3, no.2, pp.31-53.

Bodomo, A., 1997. The structure of Dagaare. CSLI: Stanford, California.

Christaller, J., 1875. A grammar of the Asante and Fante language called Twi. Basel: Basel Evangelical Missionary Society.

Dakubu, M.E.K., 1988. Ga-Dangme. In: M. E. Kropp Dakubu, ed. The languages of Ghana, pp.102118. London: Keagan Paul.

Dixon, R. M. W., 1991. A new approach to English grammar, on semantic principles. Oxford: Clarendon press.

Duthie, A. S., 1988. Ewe. In: M. E. Kropp Dakubu, ed. The languages in Ghana, pp. 91-101. New York: KPI.

Duthie, A. S., 1996. Introducing Ewe linguistic pattern. Accra: Ghana University Press.

Fillmore, C. J., 1982. Towards a descriptive framework for spatial deixis. In: R.T. Javella and W. Klein, eds. pp.31-59.

Frajzyngier, Z., 1974. Postpositions in Awutu. Journal of West African Languages, vol. 9, no. 2, 6170.

Heine, B., Ulrike, C. and Hunnemeyer, F., 1991. Grammaticalization: A conceptual framework. Chicago: The University of Chicago Press.

Hollenbach, B. E., 1995. Semantic and syntactic extensions of body part terms in Mixtecan: The case of "Face and "Foot". International Journal of American Linguistics, vol. 61, pp. 168-190.

Hopper, P., 1991. On some principles of Grammaticization. In: Traugott, Elizabeth and Bernd Heine, eds. Approaches to grammaticalization, pp.17-35. Amsterdam: John Benjamins.

Hopper, P., and Traugott, E., 2003. Grammaticalization 2nd Edition. Cambridge: Cambridge University Press.

Hudu, F., 2005. Number marking in Dagbani. MSc thesis. University of Alberta, Canada.

Jensen de López, K., 1999. The acquisition of Zapotec body-part locatives: A longitudinal case study. A paper presented to The International Congress for the Study of Child Language. San Sabastian.

Koopman, H., 2000. Prepositions, postpositions, circumpositions, and particles. In: the Syntax of Specifiers and Heads. London: Routledge, pp. 204-260.

Kuno, S., 1973. The structure of the Japanese language. Cambridge, MA: Massachusetts Institute of Technology.

Langacker, R. W., 1986. An introduction to cognitive grammar: Cognitive Science, vol. 10, pp.1-40.

Leech, G., 1974. Semantics: The study of meaning: Harmondsworth. Penguin Books.

Lillehaugen, B.D., 2003. The categorial status of body part prepositions in Valley Zapotec languages. MA thesis: UCLA.

Lyons, J., 1968. Introduction to theoretical linguistics. Cambridge: Cambridge University Press. 
MacLaury, R. E., 1989. Zapotec body-part locatives: prototypes and metaphoric extensions. International Journal of American Linguistics, vol. 55, no. 2, pp.119-154.

Muriungi, P., 2006. Categorizing adpositions in Kîitharaka, CASTL, University of Troms $\emptyset$, Norway.

Musah, A. A., 2018. A grammar of Kusaal. PhD Dissertation, Institut für Afrikanistik GoetheUniversität Frankfurt, Germany.

Naden, T., 1988. The Gur Languages. In: M. E. K. Dakubu, ed. The languages of Ghana. London: International African Institute, pp.12-49.

Naden, T., 1989. Gur. In: J. Bendor-Samuel, ed. The Niger-Congo Languages, pp.140-168.

Olawsky, K. J., 1999. Aspects of Dagbani grammar, with special emphasis on phonology and morphology, $\mathrm{PhD}$ dissertation; Munich, Lincom.

Olawsky, K. J., 2004. What is a noun? What is an adjective? Problem of classification in Dagbani. Journal of African Languages and Linguistics, vol. 25, pp. 127-148.

Osam et al., 2011. The so-called postpositions in Akan: A reconsideration. Journal of West African Languages, vol. XXXVIII, no.2 pp. 107-118.

Payne, E. T., 1997. Describing morphosyntax: A guide to field linguists. Cambridge: Cambridge University Press.

Post, M., 2007. A grammar of Galo. PhD Dissertation. Melbourne: La Trobe University Research Centre for linguistic typology.

Saanchi, J. A. N., 2003. Spatial and locative constructions in Dagaare. Legon Journal of the Humanities, vol.14, pp. 29-36.

Schaefer, P. R., and Egbokhare F. O., 2008. A preliminary assessment of Emai posture verb parameters. Journal of African Languages and Linguistics, vol. 29, pp. 215-235.

Svorou, S., 1993. The grammar of space, Amsterdam and Philadelphia: John Benjamins.

Talmy, L.,1983. How language structures space. In: H. Pick and L. Acredolo, eds. Spatial orientation: Theory, research and application. New York, Plenum Press, pp. 225-282

Talmy, L., 2000. Towards a cognitive semantics. Vol. I: Concept structuring systems. Cambridge, MA and London: MIT press.

Yahaya, R. M., 1979. The Dagbanli noun phrase: The structure and functions in Dagbanli clause structure. Long essay, Graduate diploma in Ghanaian language teaching. Legon: University of Ghana. 